reduce salmonella infection have been successful. The underlying difficulty is that salmonellae, while ubiquitous, are mostly at present cryptic. Telling whether there are bacteria in an egg, a carcass or in excreta requires that somebody should deliberately decide that some specimen or other should be sent for examination. (There is a danger that the present excitement and the requirements of the new codes of practice will quickly exhaust the available resources for bacteriological examination.) The cost of all this, in the months ahead, will be considerable. Would it not be better that there should be, instead, a programme of research designed to tackle some practical questions (How to diagnose infection more quickly? How to devise broad-spectrum vaccines?) while throwing light on more teasing conundrums?

The plain truth is that salmonellae, always with us, are here to stay. What people need in their defence against serious infection are ways of understanding the epidemiology and evolutionary biology of the bacteria. (Simple hygiene would also help.) It would plainly be a public service if there were a way of spotting in advance the emergence of bacterial attributes that are especially likely to kill people. In its response to Currie's indiscretion, the British government seems bent on mounting what looks like a campaign of salmonella eradication. Ironically, the erstwhile egg-eating population of Britain would probably be as much reassured by knowing about the uncertainties, and the prospects for their removal, as by the certainty, the way the wind is blowing, that British egg-producers will be testing everything in sight - until the demand for eggs picks up again.

What this implies is an urgent need for a more measured perspective than is likely to follow from the British government's alarm about the egg market. It would serve the public interest if some politician stood and up said that the salmonellae have been with us all for a long time, and are unlikely to be got rid of soon. Some information about the far from negligible chances of being infected except by eating eggs would also help. The news that people elsewhere are bothered by similar organisms in other domesticated animals (such as beef cattle) would paradoxically calm people's anxieties. Fears, substantial though they are, that developing societies are likely to be more afflicted would work in the other direction.

\section{Bush's budget problems}

The new US president should worry about the bills that go unpaid as well as the federal deficit.

THE next president of the United States, Mr George Bush, may be at risk of prematurely exhausting the traditional indulgence that presidential newcomers enjoy in the minds of those who have elected them to office. Bush himself is not to blame. The circumstances of the succession (an incumbent vice-president succeeding a now-recumbent president) are responsible. The result is that Bush appears to be the man already in charge, although propriety requires that he should do nothing more substantial than announce (to general applause) who his colleagues will be. A month from now, when Bush's new administration will have joined battle with the Congress on the budget for the financia' year beginning next October, the readiness to give him the benefit of the doubt may have evaporated. That will be a misfortune for Bush, but perhaps for the rest of us as well.

The problem of the US budget is now familiar: it does not balance. The reasons are simply understood. The federal government now spends more than $\$ 10^{12}$ a year - one trillion dollars, or $\$ 1,000$ billion in American usage. This vast sum consists of three roughly equal parts - defence $(\$ 300,000$ million), statutory expenditure on what are chiefly social services (more than $\$ 400,000$ million) and the rest, ostensibly in the gift of the administration and the Congress, but including spending on schemes for providing the elderly with medical care that may be abandoned only by exciting fierce political opposition. The federal deficit (this year likely to exceed $\$ 140,000$ million) is thus itself roughly a third of the federal government's apparently discretionary spending, which in itself explains why its modest reduction during the past few years has been so slow.

The argument that will begin in January has already been well rehearsed. How much, how quickly, can be quarried from the defence budget? What is the chance that doing nothing will cure the deficit because continuing prosperity brings higher incomes and disproportionately higher income taxes? What does Bush mean by a "flexible freeze"? Would a sales tax on gasoline count as a violation of promises that taxes will not go up? Even six months from now, these arid issues are unlikely to have been settled. The Democratic majorities in the Congress will have a vested interest in making the new administration swallow Bush's undertaking that taxes will not be increased, but nobody will wish to reduce spending. The potentially disastrous outcome is that issues that should be tackled, but which have been put off because of the budget deficit, will continue to wither.

Two obvious casualties of this conspiracy at neglect are the health of the US banking system (whose most lowly component, the savings and loans industry, needs between $\$ 50,000$ and $\$ 100,000$ million of new money) and the defence production reactors operated by the US Department of Energy, on which an estimated $\$ 40,000$ million must be spent in the next few years. With these clamant bills to pay, the US government is hardly in a mood to tackle problems that are more distant in the sense that their neglect will bring trouble only after the elected terms of present office-holders have elapsed. The most urgent of these is the appalling condition of public education in the United States, which has been amply catalogued during the past decade. It is mystifying that such an issue, which is widely acknowledged to be crucial to the industrial competitiveness of the United States (last year's good cause) and thus to the readiness of people elsewhere to continue financing the federal deficit, should be given so little attention.

The federal government, of course, will say that education is the responsibility of the fifty states, but that is a half-truth only. On at least two matters, the federal government's influence is decisive. First, by the provision of research grants through half a dozen agencies, the federal government helps to determine the quality of education at a small proportion of the institutes of higher education in the United States. In the battles that lie ahead, these budgets will be threatened with cuts when they should be being enlarged. Second, by its support of schemes for lending money to students for tuition payments, the federal government vitally influences access to higher education, but insufficiently. Much too little is being done to cast the net of professional training beyond those sections of the US population in which the benefits of professional training are already ingrained. While the traditional isolation of small-town rural America from wider intellectual currents may be eroded in coming decades, what benefits will that bring if the aspirations of the urban ghettos remain as impoverished as they are?

But higher education is not, in any case, conspicuously a disaster. Elementary and secondary education, especially in most major cities, is where the rot begins. The federal budget includes a few hundred million dollars for research and demonstration projects in these fields, but there is only a meagre chance that state and city governments will follow obvious precepts of good practice until the federal government is willing and able to persuade them in the right direction by spending matching funds. Nobody should be surprised that next month's budget (presented by the outgoing president and likely to be taken as a basis for negotiation by his successor) will not ask for funds for purposes such as these. The deficit is too big, and the need to reduce it too urgent. But that is a vivid illustration of how the deficit is excluding other good causes from the political agenda of the federal government. 